\title{
Ceruminous Pleomorphic Adenoma of the External Auditory Canal: Two Case Reports and Review of the Literature
}

\author{
Juyong Chung ${ }^{1}$, Dam Ho Lee ${ }^{1}$, and Keum Ha Choi ${ }^{2}$ \\ ${ }^{1}$ Departments of Otorhinolaryngology-Head and Neck Surgery, ${ }^{2}$ Pathology, Wonkwang University College of Medicine, Iksan, Korea
}

\section{외이도에 발생한 이구선 다형선종: 2증례보고 및 문헌고찰}

정주용 ${ }^{1} \cdot$ 이담호 $^{1} \cdot$ 최금하 ${ }^{2}$

원광대학교 의과대학 이비인후과학교실, ${ }^{1}$ 병리학교실 ${ }^{2}$

\author{
Received October 5, 2016 \\ Revised December 26, 2016 \\ Accepted December 27, 2016 \\ Address for correspondence \\ Keum Ha Choi, MD \\ Department of Pathology, \\ Wonkwang University \\ College of Medicine, \\ 895 Muwang-ro, Iksan 54538, Korea \\ Tel $+82-63-859-1814$ \\ Fax $+82-63-859-1819$ \\ E-mail guma337@hanmail.net
}

Ceruminous glands are specialized apocrine glands located in the external auditory canal (EAC). Pleomorphic adenoma (PA) of the EAC is derived from these ceruminous glands. Tumors arising from these ceruminous glands are rare. Furthermore, ceruminous PA of the EAC is extremely rare. About 35 cases have been reported to date in the English literature, and only 4 cases have been reported in Korea. There are several controversial issues about these rare tumors such as nomenclature, histogenesis and classification. We report here on two cases of ceruminous PA and review the cases in the Korean literature.

Korean J Otorhinolaryngol-Head Neck Surg 2017;60(4):191-5

Key Words Adenoma - Ear canal · Pleomorphic.
서 론

외이도에 발생한 다형선종은 현재까지 전 세계적으로 약 35 예밖에 보고되지 않은 매우 드문 질환이다. ${ }^{1)}$ 증례의 희소성 때문에 그동안 종양의 기원에 대한 가설이 확립되지 않았고, 또한 유사 진단명이 다양하여 환자의 치료방침 및 예후 예측 에 혼란이 있었다. 이에 저자들은 직접 치험한 2예의 외이도 다 형선종과 함께 국내 문헌에 보고된 4예의 외이도 다형선종의 임상 양상을 검토하고, 더불어 국내외 문헌고찰을 통해 외이 도 다형선종의 기원 및 통일된 진단명을 제시하고자 한다.

This is an Open Access article distributed under the terms of the Creative Commons Attribution Non-Commercial License (http://creativecommons.org/licenses/by-nc/4.0) which permits unrestricted non-commercial use, distribution, and reproduction in any medium, provided the original work is properly cited.

\section{증 려}

\section{증 례 1}

52 세 여자 환자가 1 년 전 발생한 우측 외이도 종물을 주소 로 내원하였다. 이루 및 청력저하를 호소하였고, 이 내시경상 연골부 외이도 후상방에 $1 \mathrm{~cm}$ 크기의 육아조직과 유사한 연 분홍색 종괴가 관찰되었다(Fig. 1A). 골부 외이도의 피부와 고막은 정상이었고, 청력검사 결과도 정상이었다. 측두골 컴 퓨터단층촬영 결과 연골부 외이도 후상방에서 발생한 $1 \mathrm{~cm}$ 크기의 종괴가 외이도 외측 $1 / 2$ 을 거의 폐쇄시키고 있었으며, 경계가 명확하고 골부 외이도의 침범소견은 없었다. 중이강 침범이나, 측두골 파괴소견은 없었고, 유양동 함기화는 양호 하였다(Fig. $1 \mathrm{~B}$ and C). 부분 마취하에 경외이도 접근법으로 정상 조직의 변연을 약 $2 \mathrm{~mm}$ 두고 연골막을 일부 포함하여 종물을 적출하였다. 종물 제거 후 결손부위는 특별히 재건 없 이 외이도 패킹 후 수술을 마쳤다. 현미경 소견상 상피조직과 
간엽조직으로 구성된 종양이 관찰되었으며(Fig. 1D), 2층으로 이루어진 선(gland) 구조의 내측 세포질에 특징적인 황갈색 과립이 관찰되어 이구선 다형선종으로 진단하였다(Fig. 1E). 수술 후 3년 동안 특별한 합병증이나 재발 없이 양호한 경과 를 보이고 있다.

\section{증 례 2}

73세 남자 환자가 1년 전 발생한 좌측 이폐색감을 주소로 내원하였으며, 15 년 전 만성 중이염으로 좌측 귀수술을 받은 과거력이 있었다. 이 내시경상 연골부 외이도 후상방에 압통 이 없는 단단한 종괴가 외이도를 거의 폐색시키고 있었고, 피 부나 골부 외이도는 정상이었다(Fig. 2A). 부분 마취하에 이 내접근법을 통해 $1 \mathrm{~cm}$ 크기의 연노란색 종괴를 노출시켰다.
종괴는 연골부 외이도와 골부 외이도의 접합부에 위치하였 고, 연골막 침범소견은 관찰되지 않았다. 정상 조직의 변연을 두고 연골막 일부를 포함하여 종괴를 제거하였다. 현미경 소 견상 선 구조의 상피조직과 근상피조직, 그리고 특징적인 연골 점액양 기질(chondromyxoid stroma)이 관찰되어 이구선 다 형선종으로 진단하였고(Fig. 2B), 면역조직화학염색에서 내 측 상피세포와 외측 근상피세포는 각각 cytokeratin 7(CK7) 과 S-100 protein에 양성이었다(Fig. 2C and D). 수술 후 특별 한 합병증이나 재발, 악성 변화 없이 2 년째 추적관찰 중이다.

\section{고 찰}

이구선은 변형된 아포크라인 한선으로 외이도의 연골부
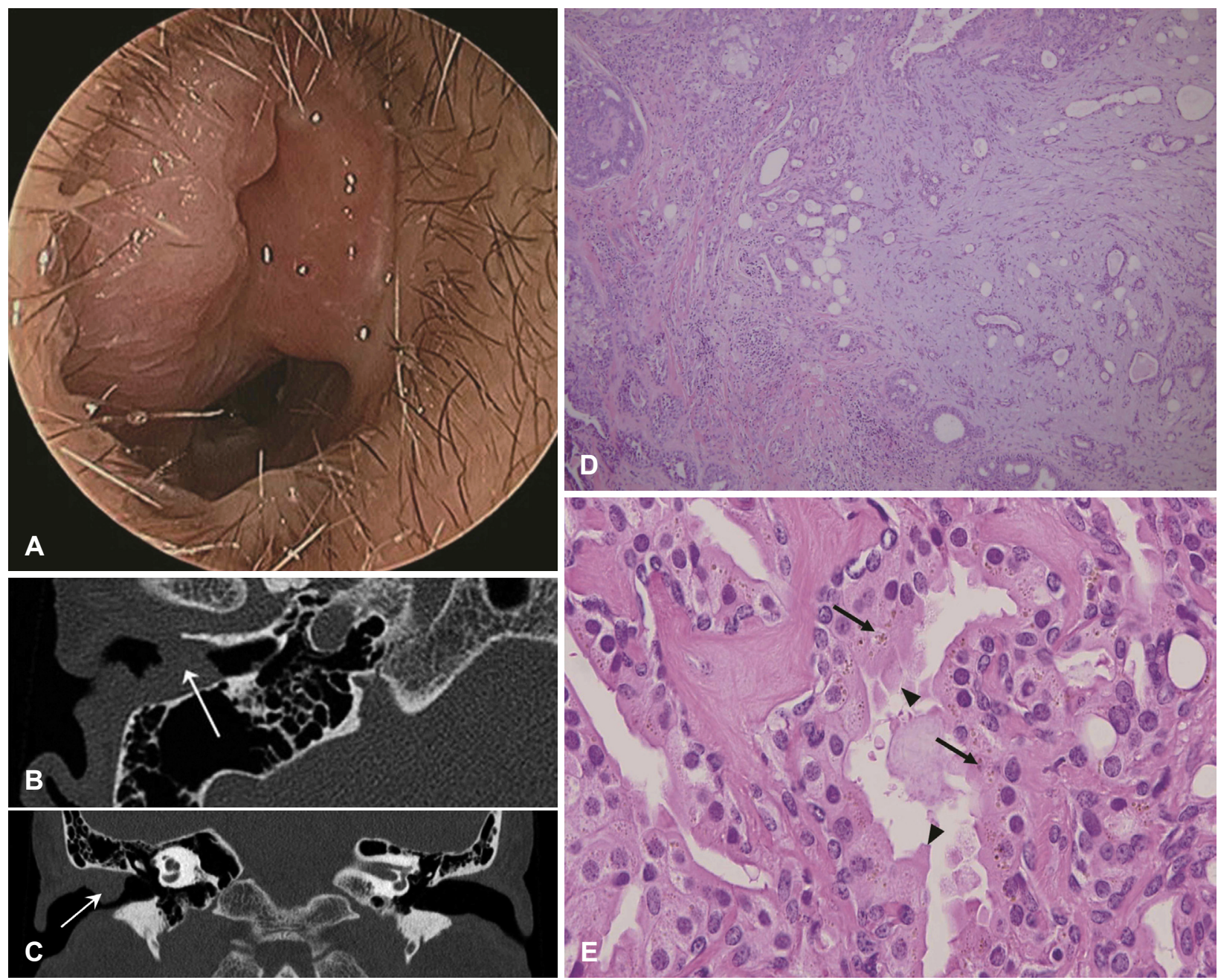

Fig. 1. Otoscopic examination shows an irregular surfaced mass originating from posteriosuperior wall of the right EAC with small amount of serous discharge (A). Axial (B) and coronal scan (C) of computed tomography of the temporal bone shows a right EAC mass (arrow) with irregular surface. There is no erosion in underlying bone of the EAC (C). Histopathological findings of the tumor show a chondromyxoid stroma admixed with epithelial and myoepithelial components (H\&E stain, $\times 100)(D)$. The epithelial cytoplasm contains the gold-to brown-colored ceroid pigment (arrows) and decapitation secretion (arrowheads) (H\&E stain, $\times 400)(E)$. EAC: external auditory canal. 


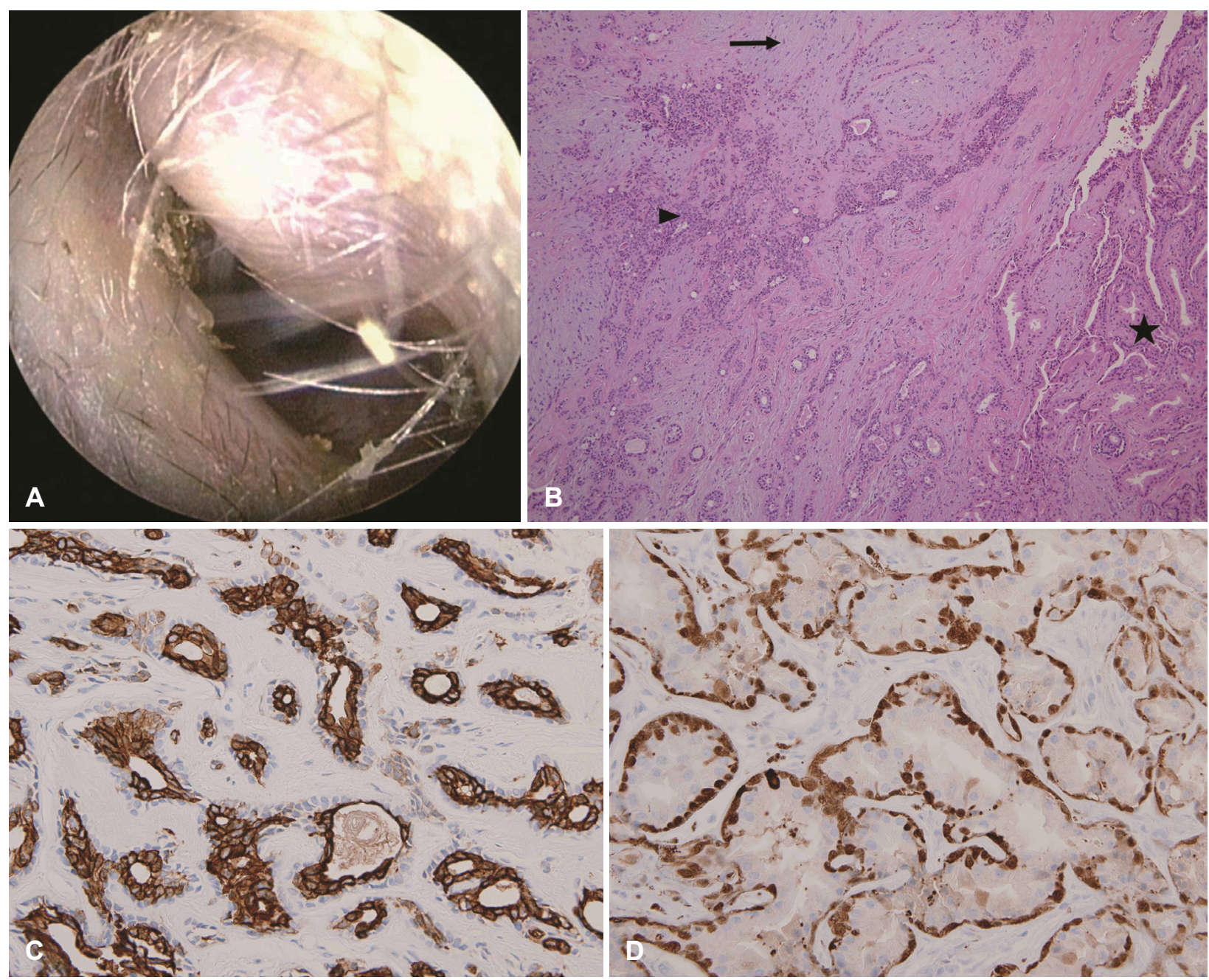

Fig. 2. Otoscopic examination shows a smooth, elevating mass originating from posterosuperior wall of the left EAC (A). Histopathological section reveals a tumor which consists of characteristic chondromyxoidstroma (arrow), myoepithelial elements (arrowhead) and glandular structures (asterisk, H\&E stain, $\times 100)(B)$. Immunohistochemical staining shows different expression of inner epithelial cells (C) $($ CK7, $\times 400)$ and outer myoepithelial cells (D) (S-100 protein, $\times 400)$. CK7: cytokeratin 7, EAC: external auditory canal.

피부에 주로 분포하며, 이구(cerumen)를 형성한다. 외이도에 서 발생한 다형선종은 이구선 종양의 한 유형으로 알려져 있 으며, 이구선 종양은 1972년 Wetli 등이 4그룹으로 분류한 이후 2그룹이 추가되어 현재는 6가지로 구분된다. ${ }^{1)}$ 양성 종양 은 1) 이구선 선종(ceruminous adenoma), 2) 이구선 다형선종 (ceruminous pleomorphic adenoma), 3) 이구선 유두상 한선 낭포선종(ceruminous syringocystadenoma papilliferum)이 며, 악성 종양은 4) 이구선암종(ceruminous adenocarcinoma), 5) 이구선 선양낭포암종(ceruminous adenoid cystic carcino$\mathrm{ma}), 6$ ) 이구선 점액상피양암종(ceruminous mucoepidermoid carcinoma)이다. 이 중 이구선 선양낭포암종이 가장 흔 하며, 이구선 다형선종이 가장 드물다. ${ }^{2}$ 양성 이구선 종양은 주변조직과의 경계가 비교적 명확하고, 세포 이형성이 거의 없으며, 유사분열지수가 매우 낮은 반면, 악성 이구선 종양은
주변조직으로 침윤하여 경계가 불명확하고, 세포 이형성이 심하며, 유사분열지수가 높다. ${ }^{3)}$ 이러한 조직학적 특징으로 양 성과 악성 이구선 종양의 감별이 가능하며, 그중 양성 이구 선 종양 간의 감별점을 살펴보면, 이구선 선종은 이구선 다 형선종과 조직학적으로 유사하나, 이구선 다형선종의 특징적 인 연골점액양 중배엽성 기질이 이구선 선종에서는 관찰되지 않는다. 또한, 이구선 유두상 한선낭포선종은 유두상 과각화 성 상피가 진피 방향으로 함입되는 특징적 소견을 보이는데, 이러한 소견은 이구선 다형선종에서는 관찰되지 않아 감별 이 가능하다. ${ }^{3}$

외이도 다형선종은 Mark와 Rothberg ${ }^{4}$ 가 1951년에 처음 보고한 이후, 문헌상 35예가 보고되었으며, ${ }^{1)}$ 국내에서는 1989 년 $\operatorname{Kim}$ 등 $^{5}$ 의 보고 이래 현재까지 4 예가 보고되었다. ${ }^{6-8)}$ 외이 도 다형선종은 그 기원에 대해 여러 주장이 있었다. 첫째, 이 
Table 1. Characteristics of ceruminous pleomorphic adenoma of the external auditory canal in Korea

\begin{tabular}{|c|c|c|c|c|c|c|}
\hline Authors & Sex/age & Origin site & Size & Symptoms & Approach & Recurrence \\
\hline$\overline{\text { Kim, et al. }} .{ }^{5}$ & $44 / \mathrm{M}$ & Rt. Post & $15 \mathrm{~mm}$ & Ear fullness/hearing loss/otorrhea & Endaural & $(-)$ \\
\hline Kim, et al. .6$)$ & $59 / F$ & Rt. Post/Sup & $10 \mathrm{~mm}$ & Ear fullness/hearing loss & Endaural & $(-)$ \\
\hline Park, et al. ${ }^{7)}$ & $57 / M$ & Rt. Ant/Inf & $10 \mathrm{~mm}$ & Ear fullness/hearing loss & Endaural & $(+)$ \\
\hline Choi, et al. ${ }^{8)}$ & $57 / F$ & Lt. Ant/Sup & $10 \mathrm{~mm}$ & Ear fullness/COM & Transcanal & $(-)$ \\
\hline Case 1 & $52 / \mathrm{F}$ & Rt. Post/Sup & $10 \mathrm{~mm}$ & Ear fullness/hearing loss/otorrhea & Transcanal & $(-)$ \\
\hline Case 2 & $73 / M$ & Lt. Post/Sup & $10 \mathrm{~mm}$ & Ear fullness/COM & Endaural & $(-)$ \\
\hline
\end{tabular}

COM: chronic otitis media, Post: posterior, Sup: superior, Ant: anterior, Inf: inferior

구선에서 기원한다는 것과 둘째, 이소성 타액선 조직에서 기 원한다는 것, 그리고 셋째, 이하선에서 발생한 다형선종이 Huschke 공(foramen) 또는 Santorini 절흔(fissure)을 통해 외이도로 침범되었다는 주장 등이 그것이다. 현재는 이구선 에서 기원한다는 주장이 가장 타당하게 받아들여지고 있으 며, 그 이유로는 면역조직화학염색에서 외이도 다형선종과 이구선 조직이 유사한 결과를 보이며, 현재까지 외이도에서 이소성 타액선 조직이 발견된 적이 없고, 타액선에서 멀리 떨 어진 피부에서 발생한 다형선종은 피부 부속기 한선에서 기 원한 종양으로 분류한다는 점을 들 수 있다." 외이도 다형선 종은 표피 혼합종, 양성 혼합종, 연골양 한관종(chondroid syringoma)으로도 불리는데, 두경부에 발생한 연골양 한관 종은 예후가 더 불량하다고 알려져 있다. ${ }^{10}$ 이와 같이 동일한 병리소견에 대해 여러 진단명을 사용할 경우, 예후 및 치료에 혼란을 줄 수 있으므로 외이도에 발생한 다형선종은 그 기원 을 고려하여 '이구선 다형선종'이라는 동일한 진단명의 사용 이 필요하다.

Saito 드ㅇㅣㅡㄴ 35 예의 외이도 다형선종을 분석하였는데, 이에 따르면 연령 분포는 15 80세, 평균 나이는 49.7세이며 성별 및 좌우측 간 발생의 유의한 차이는 없었다. 발생 위치는 후 벽 8예, 후상벽 7예, 전벽 6예, 상벽 3예, 전하벽 2예가 보고되 어, 후벽과 후상벽에서 호발하였다. 본 2증례를 포함한 국내 보고 총 6예의 평균 발생 연령은 57 세이며, 성별 및 좌우측 간 발생의 유의한 차이는 없었고, 6 예 중 4예가 후벽과 후상 벽에서 발생하여 기존 보고에 부합하였다(Table 1). 문헌상 외이도 다형선종의 평균 크기는 $1.4 \mathrm{~cm}$ 였으며, ${ }^{11)}$ 국내 보고 6 예의 평균 크기는 $1.08 \mathrm{~cm}$ 였다. 크기가 작은 종양은 전음성 난청, 외이도염 등이 주 증상인 반면, 큰 종양은 이폐색감 및 이통 등이 주 증상이다. 또한, 악성 종양은 양성 종양에 비해 이통을 더 흔히 동반하는데, 이는 악성 종양의 침윤성 성장 에 따른 증상이라 판단된다." 외이도 다형선종의 발생 원인 은 분명치 않으나, 잦은 만성 중이염 후 종양이 발생한 예가 사 람뿐 아니라 동물에서도 보고되어 이 둘의 연관성이 제기되고 있다. ${ }^{3)}$ 국내 보고 6예 중 2예에서도 만성 중이염의 과거력이 있으며, ${ }^{8)}$ 이 둘의 연관성은 앞으로 더 연구되어야 할 것이다.
영상학적 소견으로는 측두골 단층촬영상 경계가 명확한 종괴가 외이도를 폐색시키고 있는 경우가 많으며, 측두골 파 괴 및 내이의 이상 소견은 관찰되지 않았고 유양동의 함기화 는 양호하였다. 자기공명영상검사에서 $\mathrm{T} 1$ 강조영상에서는 저 강도, T2 강조영상에서는 고강도 음영을 보이며, 조영제 사용 시 증강되는 소견을 보인다. ${ }^{12)}$ 조직학적으로 이구선 다형선종 은 두 층으로 구성된 선 구조가 중배엽성 기질을 배경으로 분 포하고 있다. 내측 원주형 상피세포는 세포질 내 황갈색의 셀 로이드 색소(ceroid pigment)를 함유하고 있으며, 내강 쪽의 세포질막은 단두 분비양상(decapitation secretion)을 보인다. 이 두 가지 소견은 외이도 이외에서 발생한 다형선종에서는 관찰되지 않는 소견으로, 이구선 기원의 종양임을 알 수 있는 중요한 현미경적 소견이다(Fig. 1E). ${ }^{3)}$ 외측 입방형 근상피세포 는 기저막과 인접해 있으며, 근상피세포에서 기원하는 것으로 여겨지는 중배엽성 기질은 점액성, 연골성, 섬유성 및 골성의 다양한 형태를 보인다. 이러한 특징적인 연골점액양 기질이 적절하게 흡인된다면 세포 검사만으로도 진단이 가능하여, 술 전 치료 계획에 도움이 될 수 있다. 다형선종을 구성하는 두 가지 성분인 상피세포와 기질의 양과 성상에 따라 병리 조 직학적 아형은 세 가지로 나뉜다. 상피세포 성분이 주를 이루 는 cellular type, 기질성분 중에서도 특히 연골점액양 기질이 주를 이루는 myxoid type, 그리고 상피세포와 기질성분이 균 형 있게 배열되어 있는 classical type으로 세분할 수 있다. ${ }^{13)}$ 면역조직화학염색에서 내측 상피세포는 CK7, epithelial membrane antigen 및 gross cystic disease fluid protein-15에 양성이며, 외측 근상피세포는 S-100 protein, CK5/6 및 p63 에 양성이다(Fig. $2 \mathrm{C}$ and D). ${ }^{11,14)}$ 치료는 위족(pseudopod)을 내어 현미경적 침습을 하는 종양의 특성을 고려하여 주위 피 부나 연골막과 같은 정상 조직을 포함하여 절제하여야 한다. 이하선 다형선종의 경우 최소 $4 \mathrm{~mm}$ 이상의 변연을 확보하 여 절제하여야 한다는 보고가 있으나, 외이도 다형선종은 증 례 수가 적어 구체적인 변연에 대한 보고는 없다. ${ }^{13)}$ 따라서, 외 이도의 해부학적 구조를 고려하여 충분한 정상 조직의 변연 을 두고 연골막 일부를 포함하여 절제하여야 재발률을 낮출 수 있다. 절제연의 길이가 짧거나, 불완전 피막, 위족, 위성결 
절과 같은 특징들에 의한 종양의 불완전 절제 시 재발의 가능 성이 높다. ${ }^{13)}$ 따라서 재발을 막기 위해, 두 증례에서 모두 충분 한 정상 조직의 변연을 두고 연골막을 일부 포함하여 종양을 절제하였다. 조직학적 아형에 따라서도 재발률이 달라질 수 있으며, 연골점액양 기질이 풍부한 myxoid type이 세포 성분 이 많은 cellular type에 비해 유의하게 재발빈도가 높았다. ${ }^{13)}$ 이는 재발 원인을 제공하는 위성결절 및 불완전 피막을 동반 하는 비율이 myxoid type에서 cellular type에 비해 유의하게 높다는 점에 기인한다. ${ }^{13)}$ 이 둘의 중간에 속하는 classical type은 중등도의 재발빈도를 가지며, 본 2증례는 모두 classical type이었다. 국외 보고 35예 중 3예의 재발이 보고되었 으며," 국내 보고 6예 중 1예에서 재발이 있었다. ${ }^{7)}$ 이 증례는 4회의 레이저 수술 후에도 반복적으로 재발하여 연골막과 피부를 포함한 광범위한 절제를 추가로 시행하였으며 이후 재발하지 않았다. ${ }^{7)}$ 따라서, 단순히 종괴만을 절제하는 것은 미세현미경적 잔여 조직을 남길 수 있고, 부분적 절제가 종 양 파종을 초래할 수 있으며, 유병기간에 따라 악성화할 수 있으므로, 재발의 방지를 위해서 충분한 주위 정상 조직을 포함한 광범위한 절제와 장기간의 추적관찰이 필요할 것이 다. ${ }^{1)}$ 외이도에 발생한 양성 종양의 감별 진단 시 다형선종의 가능성을 염두에 두고 술 전 세침흡인검사를 시행하는 것이 도움이 되며, 외이도 다형선종은 그 기원을 고려하여 '이구선 다형선종'이라는 진단명으로 통일하여 사용해야 할 것이다. 또한, 다형선종의 조직학적 아형에 따라, myxoid type일 경 우 절제연을 더욱 확보하고 장기간의 추적관찰이 필요하리라 생각된다.

\section{Acknowledgments}

This paper was supported by Wonkwang University in 2016.

\section{REFERENCES}

1) Saito C, Kanazawa T, Yamaguchi T, Nakamura K, Ichimura K. Primary pleomorphic adenoma of the external auditory canal: a case report and review of the literature. Case Rep Otolaryngol 2014;2014: 975151.

2) Haraguchi $H$, Hentona $H$, Tanaka H, Komatuzaki A. Pleomorphic adenoma of the external auditory canal: a case report and review of the literature. J Laryngol Otol 1996;110(1):52-6.

3) Wisell JA, Said MS. Pathology of ceruminous gland tumors of the external auditory canal. Medscape Diseases/Conditions. 2016 Jan 31 [cited 2016 July 24]. Available from: URL: http://emedicine. medscape.com/article/1960501-overview.

4) Mark I, Rothberg M. Mixed tumor of skin of external auditory canal. AMA Arch Otolaryngol 1951;53(5):556-9.

5) Kim SI, Lee JS, Yu TH. Pleomorphic adenoma of the external auditory canal. Korean J Otolaryngol-Head Neck Surg 1989;32:945-9.

6) Kim YK, Park JH, Mun SY, Yoon YJ. A case of pleomorphic adenoma of the external auditory canal. Korean J Otolaryngol-Head Neck Surg 2001;44(1):105-7.

7) Park SY, Wi MW, Lee SY, Yang HS. Recurrent pleomorphic adenoma of the external auditory canal: a case report. J Clinical Otolaryngol 2006;17:244-7.

8) Choi KY, Kang HD, Koh ES, Park SK. A case of pleomorphic adenoma of the external auditory canal. Korean J Audiol 2010;14:45-8.

9) Ayers LS, Depasquale K, Marlowe FI, Ghaderi M. Pleomorphic adenoma of the external auditory canal: a case report and review of the literature. Ear Nose Throat J 2010;89(3):E1-3.

10) Choi DJ, Son WS, Park BC, Lee JS. A case of chondroid syringoma of the external auditory canal. Korean J Otorhinolaryngol-Head Neck Surg 2009;52(6):533-5.

11) Markou K, Karasmanis I, Vlachtsis K, Petridis D, Nikolaou A, Vital V. Primary pleomorphic adenoma of the external ear canal. Report of a case and literature review. Am J Otolaryngol 2008;29(2):142-6.

12) Masumura $C$, Horii $A$, Mishiro $Y$, Inohara $H$, Kitahara $T$, Takashima $\mathrm{S}$, et al. Magnetic resonance imaging of pleomorphic adenoma arising from the external auditory canal. J Laryngol Otol 2003;117(11):908-9.

13) Lee MY, Lee SJ, Kwon MS, Chung PS. Histopathologic analysis of parotid pleomorphic adenoma: resection margin and capsular characterisitcs. Korean J Otorhinolaryngol-Head Neck Surg 2009; 52(2):161-5.

14) Kuwabara H, Haginomori S, Takamaki A, Ito K, Takenaka H, Kurisu $\mathrm{Y}$, et al. Lipomatous pleomorphic adenoma of the ceruminous gland. Pathol Int 2006;56(1):51-3. 